\title{
THE EFFECTS OF STRATEGIC PURCHASING PRACTICES ON PERFORMANCE: AN ANALYSIS IN THE TURKISH HOSPITALITY SECTOR*
}

\author{
Oğuz AKSOY ${ }^{1}$, Melek AKIN ATEŞ²
}

\begin{abstract}
In this study, we examine the impact of strategic purchasing practices on hotel performance. In order to test our hypotheses, we use survey data from 71 hotels in Turkey. First, we perform a cluster analysis and identify two types of purchasing strategies based on supplier selection criteria: traditional vs. strategic. Then, via partial least squares (PLS) method, we test the effect of long-term relationships, supplier development and environmental supplier development on hotel performance. Our results show that long-term relationships have a negative effect on both market and financial performance. Additionally, we find that supplier development has a positive effect on performance, but only for hotels with a traditional purchasing strategy. Interestingly, we find that environmental supplier development has a positive effect on financial performance in hotels with a traditional purchasing strategy, but a positive effect on market performance in hotels with a strategic purchasing strategy.
\end{abstract}

Keywords: Hospitality Sector, Supplier Development, Supplier Relationship, Supplier Selection, Survey

JEL classification: C30, L83, M10

\section{STRATEJIKK SATIN ALMA UYGULAMALARININ PERFORMANSA OLAN ETKISII: TÜRK KONAKLAMA SEKTÖRÜNDE BİR ANALİZ}

$\ddot{O} z$

$\mathrm{Bu}$ çalışmada stratejik satın alma uygulamalarının otel performansına olan etkileri incelenmektedir. Hipotezleri test etmek için Türkiye'deki 71 otelden anket yolu ile veri toplanmıştır. İlk olarak, tedarikçi seçim ölçütlerinin kümeleme analizi ile incelenmesi ile "geleneksel" ve "stratejik" olarak adlandırılan iki farklı satın alma stratejisi bulunmuştur. Daha sonra, kısmi en küçük kareler yöntemi kullanılarak tedarikçilerle uzun vadeli ilişkilerin, tedarikçi geliştirmenin ve çevresel tedarikçi geliştirmenin otel performansına etkisi test edilmiştir. Bulgular göstermektedir ki, tedarikçilerle uzun vadeli ilişkiler otellerin pazar performansını ve finansal performansını olumsuz yönde etkilemektedir. Öte yandan, tedarikçi geliştirmenin pazar performansına ve finansal performansa olan olumlu etkisi sadece geleneksel satın alma stratejilerine sahip olan otellerde görülmüştür. Son olarak, çevresel tedarikçi geliştirme uygulamalarının geleneksel satın alma stratejisine sahip otellerde finansal performansa, stratejik satın alma stratejilerine sahip otellerde ise pazar performansına olumlu yönde etkisi olduğu gözlemlenmiştir.

Anahtar kelimeler: Anket, Tedarikçi Geliştirme, Tedarikçi İlişkileri Yönetimi, Tedarikçi Seçimi, Turizm Sektörü

JEL sinıflaması: C30, L83, M10

\footnotetext{
* This article is based on the master thesis of Oğuz Aksoy (Middle East Technical University, Graduate School of Social Sciences, 2019)

1 Oğuz Aksoy, MBA student, Middle East Technical University, oguz.aksoy@ metu.edu.tr ORCID: 0000-0002-6680-0831.

2 Asst. Prof., Melek Akın Ateş, Sabanci University, Sabanci Business School, melek.ates@sabanciuniv.edu.tr ORCID: 0000-0002-2996-5100.
} 


\section{Introduction}

Traditionally, purchasing was seen as a complementary operational activity with minor importance on firm's performance, where the main objective was to acquire the products and services with the lowest cost. (Apostolova et al., 2015; Gadde and Håkansson, 1994). However, especially in the past two decades, purchasing has transformed into a strategic function, focusing on value-adding activities such as obtaining the best quality from suppliers and involving them in joint innovation projects (Carr and Pearson, 2002; Lawson et al., 2014). While previous research illustrate that strategic purchasing practices have a positive effect on firm performance (Carr and Pearson, 2002), majority of these studies examine the manufacturing industry.

In this research, we specifically focus on the hospitality industry in Turkey. Although there have been a few studies examining strategic purchasing practices in hospitality industry (Fantazy et al., 2010; Kim, 2006), there is almost no research in the Turkish context. Being among those few studies, Önder and Kabadayı (2015) examined supplier selection criteria. In this research, we adopt a more comprehensive approach, and examine multiple strategic purchasing practices - namely, supplier selection, collaborative relationships with suppliers, supplier development, and environmental supplier development practices. Furthermore, we adopt a contingency approach, and classify hotels based on their supplier selection criteria, before testing performance effects of other strategic purchasing practices. Therefore, our main research questions are: What is the impact of strategic purchasing practices on hotel performance? Does supplier selection strategy moderate the effect of strategic purchasing practices on hotel performance?

\section{Literature Review}

Supplier Selection: Supplier selection is a strategic evaluation process that affects firm performance through supplier's performance (Luthra et al., 2017). Hence, firms try to have correct supplier selection approaches enabling them to achieve low cost, consistent high quality, and flexibility (Vonderembse and Tracey, 1999), and maintain competitive in the market and deliver products to customers on time (Kusi-Sarpong et al., 2019). Dickson (1966) has gathered the list of 23 factors to determine the ranking of supplier selection criteria, and found that the most important factor is quality followed by delivery, performance history, warranties, capacity and price. The review of Cheraghi et al. (2004) showed that new criteria have entered to supplier selection such as reliability, flexibility, consistency and long-term relationship (Cheraghi, et al. 2004). Huang and Keskar (2007) have used environmental and safety aspects in addition to traditional criteria.

Although the majority of studies about supplier selection focus on manufacturing industry, the importance of this phenomenon has also been discussed in the context of service industry. Göçen et al. (2017) have interviewed hotel managers in Antalya and determined that product quality, cost, price and delivery are the most important factors to select suppliers in tourism industry. 
Davras and Karaatlı (2014) reliability and references to this list. Önder and Kabaday1 (2015) argued that environmental policies of a supplier also need to be considered. As a result, supplier selection criteria for tourism industry were determined as quality, cost, delivery, flexibility, innovation, proximity, references and environmental sustainability. We propose that hotels do not emphasize these supplier selection criteria to the same extent, and hypothesize that:

H1: Hotels can be classified based on their emphasis on supplier selection criteria.

Collaborative Relationships: Although supplier relationships can be examined on a spectrum, two distinctive approaches are often discussed in the literature: arm's length/traditional relationships and cooperative/long-term relationships (Hoyt and Huq, 2000; Landeros and Monczka, 1989). Arm's length relationship aims to achieve competitive supply with short term orientation (Parker and Hartley, 1997). It relies on the selection of the goods or services from multiple suppliers to achieve best price where buyer firm tries to have "win-lose" situation (Lamming and Cox, 1995). This approach is argued to enable buyers to have uninterrupted flow of materials from various suppliers by using price-oriented approaches such as competitive bidding and cost-reduction analysis (Landeros and Monczka, 1989). Short-term oriented arm's length buyer-supplier relationship based on prices can prevent supply management capabilities, create distrust, and force companies to control opportunistic behavior of the partner in a complex structure (Ghoshal and Moran, 1996). Cooperative relationship aims to have fewer suppliers with the intention of continuing business and not switching supplier in the short term (Landeros and Monczka, 1989). Petersen et al. (2005) argue that close buyer-supplier relationship has many advantages such as more motivated suppliers for new product development, reduction of product costs, improvement in product quality and refined customer service issues. Building close relationships with key suppliers enables firms to eliminate many obstacles that cause delays in obtaining materials and services from suppliers (Carr and Pearson, 2002). Being among the few studies examining collaborative relationships in hospitality industry, Fantazy et al. (2010) find that the relationship with suppliers also affects customer satisfaction in the context of hotels. Therefore, we formulae the following hypothesis:

H2: Hotels that have collaborative relationship with their suppliers have better financial performance.

H3: Hotels that have collaborative relationship with their suppliers have better market performance.

Supplier Development and Environmental Supplier Development: Efforts of firms to concentrate on core competencies and increased outsourcing mostly result in increased dependence on suppliers for products and services (Krause et al., 1998). This dependence on suppliers directs buyer firms to effectively manage and develop their suppliers. Krause et al. (1998) define supplier development as efforts of buying firm to increase its supplier's performance in order to meet buying firm's objectives. 
Supplier development practices include supplier monitoring, assistance and training, provision of incentives for continuous improvement, and supplier organizational integration (De Toni and Nassimbeni, 2000).

Existing literature suggests that one advantage of performing supplier development activities is helping suppliers to increase their performance in terms of quality, delivery, cost etc. (Humphreys et al., 2004). Despite these advantages, Krause and Scannell (2002) found that firms in service industry use supplier development activities less than firms in manufacturing industry. The fact that hospitality firms' ability to provide defect-free products to their customers depends on the suppliers make hotels to rely heavily on their suppliers (Kim, 2006). As the majority of the literature argues for a positive effect (Lawson et al, 2014), we formulate the following hypothesis:

H4: Hotels that use supplier development practices have better financial performance.

H5: Hotels that use supplier development practices have better market performance.

A specific type of supplier development that is increasingly adopted is environmental supplier development. Environmental sustainability has become an important aspect for hotels since they consume vast amount of resources (Aboelmaged, 2018). Tourism industry has been blamed because of its activities that use significant amount of water resources and materials that is harmful to the nature such as plastics, non-recyclable containers, cleaning agents (RodriguezAnton et al., 2011). As a result, hotels try to handle environmental pressures from both internal and external stakeholders (Aboelmaged, 2018). One of the means to respond to the increasing pressure is to engage in environmental supplier development practices. Environmental supplier development is defined as "all activities that buyer firm helps its suppliers to reduce their negative environmental impact" (Ehrgott et al., 2013, p.131). Environmental supplier development practices include assessment and monitoring of the environmental performance of the suppliers, collaboration of buyer and supplier to achieve improvements together, and knowledge and resource transfer (Bai and Sarkis, 2010). Ağan et al. (2016) state that environmental supplier development can improve hotel performance. Thus, we propose that:

H6: Hotels that use environmental supplier development practices have better financial performance.

H7: Hotels that use environmental supplier development practices have better market performance.

\section{Research Method}

Data Collection and Sample: The unit of analysis of this study is hotels and the respondents are purchasing managers/staff, who are knowledgeable about their organization's policies. The research sample was obtained via two sources. First, we jointly worked with Hotel Purchasing Managers Education Association (OSMED). 
Executives of this association sent an online questionnaire to its members and 38 responses were collected. Additionally, a member of this association administered printed questionnaires during a meeting of the organization. As a result, 11 completed questionnaires were collected as hardcopy.

With the help of OSMED, a total of 49 responses were gathered. As the majority of the OSMED sample was from Antalya region, as a second approach we also identified a sample that includes hotels from Istanbul, Izmir, and Ankara taking into account the percentages of those in population. With that approach, an additional 22 responses were collected, resulting in a final sample of 714 -star and 5-star hotels. Table 1 illustrates the main descriptive statistics of the sample.

Table 1. Sample Descriptives

\begin{tabular}{|c|c|c|c|c|c|}
\hline City & Frequency & $\%$ & \# of Rooms & Frequency & $\%$ \\
\hline Antalya & 22 & $31.0 \%$ & $0-100$ & 8 & $11.3 \%$ \\
\hline İstanbul & 21 & $29.6 \%$ & $101-250$ & 34 & $47.9 \%$ \\
\hline Ankara & 9 & $12.7 \%$ & $251-500$ & 25 & $35.2 \%$ \\
\hline Muğla & 6 & $8.5 \%$ & $500+$ & 4 & $5.6 \%$ \\
\hline İzmir & 4 & $5.6 \%$ & Total & 71 & $100 \%$ \\
\hline Aydın & 2 & $2.8 \%$ & & & \\
\hline Bursa & 2 & $2.8 \%$ & \# of Employees & Frequency & $\%$ \\
\hline Afyon & 2 & $2.8 \%$ & $0-100$ & 22 & $31.0 \%$ \\
\hline Gaziantep & 1 & $1.4 \%$ & $101-250$ & 30 & $42.2 \%$ \\
\hline Samsun & 1 & $1.4 \%$ & $251-500$ & 13 & $18.3 \%$ \\
\hline Trabzon & 1 & $1.4 \%$ & $500+$ & 6 & $8.5 \%$ \\
\hline Total & 71 & $100 \%$ & Total & 71 & $100 \%$ \\
\hline
\end{tabular}

Measurement: Survey questions were prepared based on an extensive literature search. Questions were formulated with a five-point Likert scale, with answer options ranging from "1 Strongly disagree" to "5-Strongly agree". Accordingly, policies of hotels in terms of Supplier Selection (SS), Supplier Relationship (SR), Supplier Development (SD), Environmental Supplier Development (ESD), Market Performance (MP) and Financial Performance (FP) were measured. Due to space constraints, list of questions is not provided; instead, a brief description of the items and the sources are discussed below.

All constructs had multi-item measures. Seven supplier selection criteria were determined after reviewing studies regarding hospitality industry reviewed: quality, cost, delivery, flexibility, proximity, references, and environmental sustainability. Studies by Zeller and Drescher (2017) and Önder and Kabadayı (2015) were used for cost, delivery, proximity, references and sustainability criteria, and items by Krause et al. (2001) were used for quality and flexibility criteria. Collaborative relationships were assessed by adopting the items of Fantazy et al. (2010) focusing on long-term orientation of hotels on managing their relationships with their suppliers. Supplier development items included aspects such as monitoring, assessment, and guidelines related to performance improvement and training of suppliers (Kim (2006). 
Items related to environmental supplier development were developed based on Ağan et al. (2016), who emphasized the above supplier development items focusing specifically on environmental performance improvements. Hotel performance was assessed in two dimensions: financial performance and market performance.

Financial performance was measured with market share, profitability, net profit, and annual growth, whereas market performance was measured with customer satisfaction, customer loyalty, product/service quality and sustainability.

\section{Results}

Cluster Analysis: The first hypothesis of the study predicts that hotels can be grouped in terms of their supplier selection criteria. In order to do so, two-step cluster analysis (hierarchical clustering and k-means clustering) was used, with the objective of finding groups that exhibit high internal homogeneity (within-cluster) and high external (between-cluster) heterogeneity (Hair et al., 2010). Pseudo-F statistics suggested a two-cluster solution (Wilkinson et al., 2000). The means of the cluster variables are presented in Table 2. Cluster 1 is labeled as "Strategic". This cluster represents a group of hotels that emphasize all supplier selection criteria. Hotels in this group choose their suppliers not only by requiring qualified products with lower prices, but also adaptive suppliers with flexible, environmentally friendly products. Also regional proximity and coverage is an important aspect for the hotels in that cluster. This cluster can be associated with strategic sourcing as well since strategic purchasing includes not only cost, quality, delivery but also many other criteria such as innovativeness and supplier's capabilities. Cluster 2 is labeled as "Traditional". Hotels in this group emphasize cost and quality as much as those in Cluster 1. Moreover, the third most important dimension in selection of suppliers is delivery performance. References and flexibility of suppliers have only moderate score, and environmental qualifications and regional proximity of suppliers are of minor importanc. In this group, hotels adopt traditional purchasing practices by focusing on having high quality with lowest cost in a fast-paced manner (Das et al., 2006). We predict that in these two groups, strategic purchasing practices will have different effects on hotel performance.

Table 2. Cluster Analysis Results

\begin{tabular}{lcccc}
\hline & C1. Strategic $(\mathrm{n}=38)$ & C2. Traditional $(\mathrm{n}=33)$ & F-Statistics & Significance \\
\hline Cost & 4.76 & 4.71 & 0.62 & 0.435 \\
Quality & 4.91 & 4.86 & 0.36 & 0.548 \\
Delivery & 4.87 & 4.56 & 13.35 & 0.000 \\
Flexibility & 4.66 & 4.19 & 13.15 & 0.001 \\
References & 4.82 & 4.21 & 28.24 & 0.000 \\
Proximity & 4.12 & 2.95 & 55.21 & 0.000 \\
Environmental & 4.57 & 3.67 & 42.06 & 0.000 \\
\hline
\end{tabular}


Partial Least Squares (PLS) Method: In order to test our hypotheses, partial least squares (PLS) method is used. PLS enables conducting analyses when data is not normally distributed and sample size is low (Chin, 1998). The review by Ali et al. (2017) showed that PLS is very popular in the hospitality literature. SmartPLS 3. software was used and results were obtained via two sequential steps: i) evaluation of the reliability and validity of the measurement model, and ii) evaluation of the structural model.

Reliability and validity. Reliability was assessed by Cronbach alpha values, which ranged between 0.692 and 0.920 , assuring high levels of reliability. Validity was assessed by convergent validity and discriminant validity. In order to ensure convergent validity, item loadings should be higher than 0.7 for corresponding construct. In our case, item loadings ranged between 0.685 and 0.953. Furthermore, Average Variance Extracted (AVE) is used to determine the amount of variance captured by a construct and whether there is a measurement error. Values above 0.7 are considered very well and level of 0.5 is acceptable (Fornell \& Larcker, 1981). AVE for our constructs ranged between 0.602 and 0.867 . Finally, to ensure discriminant validity, square root of AVEs should be higher than inter-construct correlations (Chin, 1998). As Table 3 illustrates, this was the case for all our constructs, suggesting that we can proceed with the structural model.

Table 3. Discriminant Validity

\begin{tabular}{lccccc}
\hline & $(1)$ & $(2)$ & (3) & (4) & (5) \\
\hline (1) Collaborative Relationship & 0.776 & & & & \\
(2) Supplier Development & 0.511 & 0.865 & & & \\
(3) Environmental Supplier Development & 0.253 & 0.148 & 0.929 & & \\
(4) Financial Performance & -0.058 & 0.196 & 0.287 & 0.876 & \\
(5) Market Performance & -0.168 & 0.069 & 0.247 & 0.432 & 0.846 \\
\hline
\end{tabular}

Structural model. In order to test the significance of the relationships in the structural model, we used a bootstrapping procedure with 1000 re-samples (Tenenhaus et al. 2005) to calculate the tstatistics for the hypothesized relationships. The results of this analysis are shown in Table 4.

Table 4. PLS Results

\begin{tabular}{lccc}
\hline Path & Path Coef. & T Statistics & P Values \\
\hline H2: Collaborative Relationship » Financial Performance & -0.290 & 1.626 & 0.099 \\
H3: Collaborative Relationship » Market Performance & -0.349 & 1.866 & 0.062 \\
H4: Supplier Development » Financial Performance & 0.297 & 1.578 & 0.115 \\
H5: Supplier Development » Market Performance & 0.202 & 1.024 & 0.306 \\
H6: Env. Supplier Development » Financial Performance & 0.316 & 2.862 & 0.004 \\
H7: Env. Supplier Development » Market Performance & 0.305 & 3.079 & 0.002
\end{tabular}


Accordingly, Collaborative Relationship was expected to be positively effective; however, it was found that it has a significant negative effect on both Financial Performance $(\Upsilon=-0.290$, $\mathrm{p}=0.099)$ and Market Performance $(\Upsilon=-0.349, \mathrm{p}=0.062)$. Therefore, $\mathrm{H}_{2}$ and $\mathrm{H}_{3}$ are not supported. Supplier Development was found to have a positive effect on both Financial Performance $(\Upsilon=0.297, p=0.115)$ and Market Performance $(\Upsilon=0.202, p=0.306)$; however, effects were not statistically significant. Therefore, $\mathrm{H}_{4}$ and $\mathrm{H}_{5}$ are not supported.

As it was expected, Environmental Supplier Development had a significantly positive effect on both Financial Performance $(\Upsilon=0.316, p=0.004)$ and Market Performance $(\Upsilon=0.305, p=0.002)$, thus supporting $\mathrm{H}_{6}$ and $\mathrm{H}_{7}$. The independent variables explained $16.6 \%$ and $14.8 \%$ of the variance in Financial Performance and Market Performance, respectively.

By using the outputs of cluster analysis, two groups of hotels - Strategic and Traditional - are analyzed by multi-group analysis in PLS. The results for each group are presented in Table 5.

Table 5. Multi-group Analysis

\begin{tabular}{lcccccccc}
\hline & \multicolumn{3}{c}{ Cluster 1 (Strategic) } & \multicolumn{4}{c}{ Cluster 2 (Traditional) } \\
Path & $\mathrm{H}$ & Path C. & $\mathrm{T}$ & $\mathrm{P}$ & $\mathrm{H}$ & Path C. & $\mathrm{T}$ & $\mathrm{P}$ \\
\hline Collaborative Relationship » Financial Perf. & $\mathrm{H}_{2 \mathrm{a}}$ & -0.060 & 0.265 & 0.791 & $\mathrm{H}_{2 \mathrm{~b}}$ & -0.345 & 1.372 & 0.170 \\
Collaborative Relationship » Market Perf. & $\mathrm{H}_{3 \mathrm{a}}$ & -0.233 & 1.240 & 0.215 & $\mathrm{H}_{3 \mathrm{~b}}$ & -0.410 & 1.248 & 0.212 \\
Supplier Development » Financial Perf. & $\mathrm{H}_{4 \mathrm{a}}$ & -0.323 & 1.010 & 0.312 & $\mathrm{H}_{4 \mathrm{~b}}$ & 0.491 & 2.619 & 0.009 \\
Supplier Development » Market Perf. & $\mathrm{H}_{5 \mathrm{a}}$ & -0.231 & 1.181 & 0.238 & $\mathrm{H}_{5 \mathrm{~b}}$ & 0.461 & 1.675 & 0.094 \\
Env. Supp. Development » Financial Perf. & $\mathrm{H}_{6 \mathrm{a}}$ & 0.180 & 0.908 & 0.364 & $\mathrm{H}_{6 \mathrm{~b}}$ & 0.368 & 2.361 & 0.018 \\
Env. Supp. Development » Market Perf. & $\mathrm{H}_{7 \mathrm{a}}$ & 0.476 & 2.917 & 0.004 & $\mathrm{H}_{7 \mathrm{~b}}$ & 0.174 & 0.674 & 0.501 \\
\hline
\end{tabular}

For Cluster 1 (Strategic group), we found that Collaborative Relationships had no effect on Financial performance $(\Upsilon=-0.060, p=0.791)$ and Market Performance $(\Upsilon=-0.233, p=0.215)$. Similarly, For Cluster 2 (Traditional group), Collaborative Relationships had a negative effect on both Financial Performance $(\Upsilon=-0.345, p=0.170)$ and Market Performance $(\Upsilon=-0.410$, $\mathrm{p}=0.212$ ), but the effects were not statistically significant.

Surprisingly, we found that Supplier Development had a positive effect on Financial Performance $(\Upsilon=0.491, \mathrm{p}=0.009)$ and Market Performance $(\Upsilon=0.461, \mathrm{p}=0.094)$ only in Cluster 2 (Traditional group). These relationships were negative for Cluster 1 (Strategic group) for both Financial Performance $(\Upsilon=-0.323, p=0.312)$ and Market Performance $(\Upsilon=-0.231, p=0.238)$, but the effects were not statistically significant.

Finally, we found that while Environmental Supplier Development had a positive effect on Market Performance $(\Upsilon=0.476, p=0.004)$ in Cluster 1 (Strategic group), it had no effect on Financial Performance $(\Upsilon=0.180, \mathrm{p}=0.364)$. In contrast, in Cluster 2 (Traditional group), Environmental Supplier Development had a positive effect on Financial Performance $(\Upsilon=0.368$, $\mathrm{p}=0.018)$, whereas it had no effect on Market Performance $(\Upsilon=0.174, \mathrm{p}=0.501)$. 


\section{Discussion}

This study has examined the key strategic purchasing practices highly discussed in the literature - supplier selection, supplier relationship management, supplier development - in a less conventional setting, namely hospitality sector in service industry. Therefore, findings of this study may provide an important guidance for both academicians and practitioners in hospitality industry.

First of all, hotels are divided into two significant groups - Strategic and Traditional - in terms of their supplier selection processes. We found that the two groups do not have significant difference in terms of cost and quality. This finding is similar to the study of Önder and Kabadayı (2015) and Davras and Karaatli (2014), where these criteria were found to be the most important supplier selection criteria. The two groups are significantly different in terms of delivery, proximity, references, flexibility and environmental sustainability. Strategic group has significantly higher scores in all of those criteria than Traditional group. Hotels in Strategic group want to have geographically close and flexible suppliers to meet changes in demands and have suppliers that can respond their organization quicker. Moreover, they seek reputable and well-known suppliers that can also offer environmentally products and services enabling them to gain competitive advantage.

Second, creating collaborative relationship with suppliers is found to have significantly negative effects on financial and market performance. This is an unexpected and interesting finding since Fantazy et al. (2010) found that creating collaborative relationships with suppliers positively affects financial and non-financial performance of buyer hotels. Similarly, many studies advocate that collaborative or long-term oriented relationships with suppliers have positive effects on both suppliers' and buyers' performance (Kähkönen et al., 2017). The fact that most of these studies were conducted in developed countries such Canada, Finland makes us to consider origin of this study, a developing country, might be one of the explanations behind this finding. Öztüren and Sevil (2009) studied collaborative relationships of hotels in North Cyprus which has a similar environment to Turkey. Accordingly, they found that hotels tend to have collaborative relationships with their customers, but not with their suppliers. Furthermore, they also found that collaborative relationship with suppliers was not associated with higher net profits, customer satisfaction and annual growth. Another explanation might relate to the darkside of close relationships; Villena et al. (2011) noted that collaborative or long-term oriented relationships enables one side of partnership to abuse relationship and negatively affect performance of both sides. Finally, as one of the hotel managers stated during the survey pretesting stage, in Turkey, long-term oriented relationships with suppliers may be perceived as fraud or corruption. Therefore, purchasing managers in Turkey may want to avoid such accusations.

Many studies argued that supplier development activities increases performance of both suppliers (Modi and Mabert, 2007; Lawson et al., 2014) and buyers (Kim, 2006; Humphreys et al., 2004). 
In the overall model, we found that supplier development had no effect on performance. However, multi-group analysis revealed that supplier development had a positive effect on only in the Traditional group. At first glance, this finding seems controversial as supplier development is an advanced strategic purchasing practice. Supplier development activities in this study include evaluating, visiting and helping suppliers to increase their performance. In other words, there should be room for improvement to have solid outputs after performing development activities. Therefore, positive effects of supplier development on performance of Traditional group may be associated with the suppliers' capability and availability for improvement. As Strategic group focus on all selection criteria, it can be concluded that the suppliers in this group already have higher capability and capacity. It could also be the case that hotels in Strategic group use supplier development activities not to develop, but to maintain the current performance of suppliers.

Finally, as it is expected, environmental supplier development has significantly positive effects on financial and market performance of hotels. Aboelmaged (2018) stated that competitive advantage can be achieved by adopting green practices and environmental strategies and practices provide competitive advantage over rivals in terms of cost, delivery and service quality. Interestingly, multi-group analysis showed that Strategic group benefits from environmental supplier development in terms of market performance while Traditional group benefits in terms of financial performance. This finding might be related to the type of environmental development. In the context of hotels, the outsourced products/services in terms of environmental management have a great mix. These products may be used to preserve water (e.g. sewage treatment plant, reuse of treated water for cooling), energy (e.g. low temperature systems in laundry, use of sensors in lightning, solar panels), waste (e.g. waste management, waste separation, and recovery of oils from waste food) or may be related to other resources (Menezes and da Cunha, 2016). Therefore, customers may not even see or interact with all of these products since they are used at the back stage. Hotels in Traditional group may use and encourage their suppliers to produce or supply environmental friendly products/services related to cost saving. Therefore, the only outcome would be effective on financial performance while customers do not even realize. However, hotels in Strategic group use significantly more environmental supplier development practices than Traditional. Consequently, one can argue that cost-saving product/services used by Traditional group have already been adopted to a high extent by Strategic group. Instead, the main goal might be attracting customers by promoting environment-friendly products. Since the literature suggests that customers are willing to pay more and revisit environmental friendly hotels (Lee et al., 2010), hotels in Strategic group strategically focus on products/services that customers interact, use or consume, and therefore gain better market performance. 


\section{Conclusion}

This study contributes to the literature by adopting a comprehensive approach to investigate strategic purchasing practices in a less examined context; hospitality industry in a developing country. Our results illustrate the need to first differentiate between hotels' purchasing strategies based on their supplier selection criteria, as we find different effects of strategic purchasing practices in each group. Furthermore, some controversial findings such as negative effects of collaborative relationships provide support for the more recently advocated arguments such as dark side of close relationships (Villena et al., 2011).

Our study also has some managerial implications. Turkish hospitality industry hosted over 46 million visitors in 2018 (Ministry of Culture and Tourism, 2019). This study presents contributions to managers of hotels, suppliers and also regulatory bodies. Unlike the literature, this study showed that better performing hotels do not create collaborative relationships with their suppliers. In light of this information, hotel managers can approach creating collaborative relationship cautiously to have better financial and market performance. Additionally, supplier development practices are significantly associated with business performance for hotels that have Traditional purchasing strategy. Hence, managers in this group should take advantage of adopting supplier development activities. Moreover, environmental supplier development activities are positively related to hotel performance. Tourism industry has been blamed because of its activities that use significant amount of resources. This study shows the potential improvement areas regarding environmental management to break down the prejudices. Manager should allocate required resources to shift firm strategy towards environmental integration (Aboelmaged, 2018) and invest in environmental supplier development activities to increase financial and market performance.

As with any other research, this study is not without limitations. First of all, we have a limited sample size. To counteract this issue, we paid special attention that the sample demographics are proportional to those of the population of hotels in those cities. Second, data has been collected from single respondents and there might be issues regarding subjectivity. However, in many hotels purchasing activities are managed by a single person; therefore, it was not feasible in many cases to identify multiple respondents. Third, data has been collected in a crosssectional way. Future research can aim for assessing performance in a longitudinal way. Notwithstanding these limitations, we hope that this study fills an important gap in the literature with several interesting findings illustrating performance implications of strategic purchasing practices in the hospitality industry.

\section{References}

Aboelmaged, M. (2018). The drivers of sustainable manufacturing practices in Egyptian SMEs and their impact on competitive capabilities: A PLS-SEM model. Journal of Cleaner Production, 175, 207-221.

Ağan, Y., Kuzey, C., Acar, M.F., \& Açıkgöz, A. (2016). The relationship between corporate social responsibility, environmental supplier development, and firm performance. Journal of Cleaner Production, 112(3), 1872-1881. 
Ali, F., Rasoolimanesh, S. M., Sarstedt, M., Ringle, C. M., \& Ryu, K. (2018). An assessment of the use of partial least squares structural equation modeling (PLS-SEM) in hospitality research. International Journal of Contemporary Hospitality Management, 30(1), 514 538.

Apostolova, B.Z., Kroon, M.J., Richter, M., \& Zimmer, I.M., (2015). Strategic purchasing: A global perspective. University of Groningen.

Bai, C., \& Sarkis, J. (2010). Green supplier development: analytical evaluation using rough set theory. Journal of Cleaner Production, 18(12), 1200-1210.

Carr, A.S., \& Pearson, J.N. (2002). The impact of purchasing and supplier involvement on strategic purchasing and its impact on firm's performance. International Journal of Operations \& Production Management, 22(9), 1032-1053.

Cheraghi, S.H., Dadashzadeh, M., \& Subramanian, M. (2004). Critical success factors for supplier selection: An update. Journal of Applied Business Research, 20(2), 91-108.

Chin, W.W. (1998). The Partial Least Squares Approach for Structural Equation Modeling, in: Modern Methods for Business Research, G.A. Marcoulides (ed.), Lawrence Erlbaum Associates, Mahwah, NJ, pp. 295-336.

Das, A., Narasimhan, R., \& Talluri, S. (2006). Supplier integration-finding an optimal configuration. Journal of Operations Management, 24(5), 563-582.

Davras, G.M., \& Karaatlı, M. (2014). Otel işletmelerinde tedarikçi seçimi sürecinde AHP ve BAHP yöntemlerinin uygulanması. Hacettepe Üniversitesi İktisadi ve İdari Bilimler Fakültesi Dergisi, 32(1), 87-112.

De Toni, A. \& Nassimbeni, G. (2000). Just-in-time purchasing: An empirical study of Operational Practices, Supplier Development and Performance. Omega, 28, 631-651.

Dickson, G. W. (1966). An analysis of vendor selection systems and decisions. Journal of Purchasing, 2(1), 5-17.

Ehrgott, M., Reimann, F., Kaufmann, L., \& Carter, C.R (2013). Environmental development of emerging economy suppliers: Antecedents and outcomes. Journal of Business Logistics, 34, 131-147.

Fantazy, K.A., Kumar, V., \& Kumar, U. (2010). Supply management practices and performance in the Canadian hospitality industry. International Journal of Hospitality Management, 29(4), 685-693.

Fornell, C., \& Larcker, D. F. (1981). Evaluating structural equation models with unobservable variables and measurement error. Journal of Marketing Research, 18(1), 39-50.

Gadde, L.E., \& Håkansson, H. (1994). The changing role of purchasing: reconsidering three strategic issues. European Journal of Purchasing \& Supply Management, 1(1), 27-35.

Ghoshal, S., \& Moran, P. (1996). Bad for practice: A critique of the transaction cost theory. Academy of Management Review, 21(1), 13-47.

Göçen, S., Albeni, M., Yirik, Ş., Yildiz, H., \& Akdere, M. (2017). Competition, market structure and market power within the hotel-supplier sector in Antalya, Turkey: The case for technology integration. Tourism Economics, 23(3), 647-668.

Hoyt, J., \& Huq, F. (2000). From arms-length to collaborative relationships in the supply chain: An evolutionary process. International Journal of Physical Distribution \& Logistics Management, 30(9), 750-764.

Huang, S.H., \& Keskar, H. (2007). Comprehensive and configurable metrics for supplier selection. International Journal of Production Economics, 105(2), 510-523.

Humphreys, P.K., Li, W.L., \& Chan, L.Y. (2004). The impact of supplier development on buyer-supplier performance. Omega, 32(2), 131-143. 
Kähkönen, A.K., Lintukangas, K., Ritala, P., \& Hallikas, J. (2017). Supplier collaboration practices: Implications for focal firm innovation performance. European Business Review, 29(4), 402-418.

Kim, B.Y. (2006). The impact of supplier development on financial performance in the restaurant industry. International Journal of Hospitality \& Tourism Administration, 7(4), 81-103.

Krause, D.R., Handfield, R B., \& Scannell, T.V. (1998). An empirical investigation of supplier development: reactive and strategic processes. Journal of Operations Management, 17(1), 39-58.

Krause, D.R., \& Scannell, T.V. (2002). Supplier development practices: product- and servicebased industry comparisons. The Journal of Supply Chain Management, 38(2), 13-21.

Krause, D.R., Pagell, M., \& Curkovic, S. (2001). Toward a measure of competitive priorities for purchasing. Journal of Operations Management, 19(4), 497-512.

Kusi-Sarpong, S., Gupta, H., \& Sarkis, J. (2018). A supply chain sustainability innovation framework and evaluation methodology. International Journal of Production Research, 57 (7), 1-19.

Landeros, R., \& Monczka, R. M. (1989). Cooperative buyer/seller relationships and a firm's competitive posture. Journal of Purchasing and Materials Management, 25(3), 9-18.

Lawson, B., Krause, D., \& Potter, A. (2014). Improving supplier new product development performance: The role of supplier development. Journal of Product Innovation Management, 32(5), 777-792.

Lee, J. S., Hsu, L. T., Han, H., \& Kim, Y. (2010). Understanding how consumers view green hotels: How a hotel's green image can influence behavioural intentions. Journal of Sustainable Tourism, 18(7), 901-914.

Luthra, S., Govindan, K., Kannan, D., Mangla, S. K., \& Garg, C. P. (2017). An integrated framework for sustainable supplier selection and evaluation in supply chains. Journal of Cleaner Production, 140, 1686-1698.

Modi, S. B., \& Mabert, V. A. (2007). Supplier development: Improving supplier performance through knowledge transfer. Journal of Operations Management, 25(1), 42-64.

Menezes, V., \& da Cunha, S. (2016). Eco-Innovation in global hotel chains: designs, barriers, incentives and motivations. Brazilian Business Review, 13, 108-128.

Önder, E., \& Kabadayi, N. (2015). Supplier selection in hospitality industry using ANP. International Journal of Academic Research in Business and Social Sciences, 5(1).

Öztüren, A., \& Sevil, G. (2009). Supply chain management as a sustainable performance booster for the accommodation enterprises: evidence from North Cyprus tourism sector. International Journal of Business and Management, 4(2), 97-111.

Tenenhaus, M., Amato, S., \& Esposito Vinzi, V. (2004). A global goodness-of-fit index for PLS structural equation modelling. In Proceedings of the XLII SIS scientific meeting (1), 739-742.

Villena, V. H., Revilla, E., \& Choi, T. Y. (2011). The dark side of buyer-supplier relationships: A social capital perspective. Journal of Operations Management, 29(6), 561-576.

Vonderembse, M.A., \& Tracey, M. (1999). The impact of supplier selection criteria and supplier involvement on manufacturing performance.Journal of Supply Chain Management, 35(2), 33-39.

Wilkinson, L., Engelman, L., Corter, J., \& Coward, M. (2000). Cluster analysis. In L. Wilkinson (Ed.), Systat 10 - Statistics I (pp. 65-124). Chicago, IL: SPSS Inc.

Zeller, M., \& Drescher, F. (2017). Procurement management in the German restaurant industry: A comparison between top 100 restaurants and smaller restaurants. Journal of Culinary Science \& Technology, 15(4), 360-379. 